\title{
An Empirical Study on the Scientific Transformation of Newly-built Local Universities
}

\author{
Peng Xinping, Deng Yonggang, Zhang Xiumei
}

Pingxiang University, Pingxiang, Jiangxi, 337000

Keywords: application-oriented undergraduate education; transformation

\begin{abstract}
Application-oriented undergraduate education is applied to the higher education in order to serve the needs of economic and social development, for the local economy, industry and production services line, training knowledge, ability and quality of the all-round development of advanced applied talents of higher education. For these benefits, it is necessary to accelerate the transformation and development of newly-built local colleges and universities, so that the newly-built local colleges and universities can enter the training of applied talents as soon as possible.
\end{abstract}

\section{Introduction}

Application-oriented undergraduate education has many characteristics, which are mainly reflected in the following points:

(1) The goal of talent training is advanced application talents. Different from the cultivation of research-oriented academic talents in ordinary universities, the goal of talent training in applied undergraduate education is to solve problem-solving problems. It is oriented toward the front line of production and services and can better meet job requirements. It is highly qualified for practical hands-on ability and innovation ability. Compared with higher vocational education, the undergraduate education of applied undergraduate education emphasizes both "theoretic teaching and practical teaching”to enable students to have independent problem-solving and innovative abilities.

(2) The service orientation of the application-oriented undergraduate education is to directly serve the local economy, and is oriented toward the development of the industry and the first line of production services. It is necessary to serve the local pillar industries so as to harmonize the development of the colleges and universities and the development of the local economy and effectively solve the local employment problems [1].

\section{The Difficulties and Problems in the Transformation}

Although the transformation of local colleges and universities has become irreversible and the direction of transformation has been quite clear, the real operation process is difficult and challenging. The transformation of general teaching-type undergraduate colleges into application-oriented universities is conducive to educating such universities to go beyond traditional "elite education" schooling concepts, "research-based" school-running models and "academic" talent-training models, and better cultivate local-oriented education. In reality, many local universities have not been able to successfully implement this transformation. From the analysis of subjective and objective factors, the difficulties are mainly in the following aspects.

(1) Lagging behind the change of educational philosophy

Under the background that higher vocational colleges have been upgraded to undergraduate colleges, higher vocational colleges have been operating for a long time and many schooling concepts have been deeply entrenched. It is very difficult to change concepts [2].

(2) Weak foundation for running a school

Compared with universities directly under the state, local universities have some restrictions on their own development and realization of university functions, such as their own lack of resources, 
the limitations of investment in education, research funding is too small, etc. Some professional adjustments have been made, and some so-called popular majors have been newly created. However, these majors have often been rushed to launch under the condition that teachers do not have the qualifications, the disciplines are not complete, and the curriculum system is not sound [3].

(3) Inaccurate orientation of running school

The orientation of running schools is based on the nature of colleges and universities, the basis and conditions for running schools, social needs as a guide, and the purpose of promoting school development. It is a combination of the country's higher education policy and the expectations of all sectors of society, as well as the resources available within the school. Determine the school's educational goals and development direction.

(4) Features convergence

In the actual development process, the newly-built undergraduate colleges have a phenomenon of lack of characteristics and characteristics convergence. Local colleges and universities do not seek characteristics in their own types and levels. Instead, they imitate and even copy old colleges and universities in the setting of professional disciplines, service orientation, and talent training, and basically "conformalize” with established colleges and universities.

(5) The overall strength of teachers is weak and the structure is not reasonable

The overall strength of the teaching force is weak, the structure of teachers is irrational, there are fewer teachers with higher professional qualifications and higher academic qualifications, and there is less scientific research ability. In particular, the number of application-oriented teachers is low, and teachers need to go to the company for job placement or internships. Improve the practical ability to better train application-oriented undergraduate talents.

(6) Single talent training model

Local undergraduate colleges and universities have carried out many reforms in the personnel training model for many years. Their expansion is mainly in the form of "studies of engineering and learning", and the model is relatively single. Many school-enterprise cooperation is merely in the form of signing an agreement to hang a license. There is no real student participation in the company for visits and internships. Many newly-built local undergraduate colleges still cultivate paper-theoretic talents. Graduates lack the vocational skills required for their jobs and become "bottleneck" restrictions for the cultivation of applied talents.

(7) The problem of teaching materials construction is becoming increasingly prominent

Now the school's training objectives have changed. It is to cultivate applied undergraduates. However, in most local universities, there is no qualitative change in textbook construction, and academic textbooks are still being used. At most, the original textbooks are slightly modified. If we do not pay attention to the reform of textbooks, the quality of teaching in local universities cannot be guaranteed.

(8) The concept of "lower first class" in vocational education is deeply rooted

In our country's education system, there has long been a traditional concept of focusing on systematic knowledge teaching and light practical ability training, and this concept is deeply rooted in people's minds. From the perspective of enrollment, most of the students in higher vocational colleges are those with low college entrance examination scores or college entrance exams.Affected by these traditional ideas, the transformation and development of local undergraduate colleges into applied technology-oriented universities is difficult to accept in a short period of time. This seemingly "degradation" of undergraduate colleges and universities will eventually become a "stumbling block" for transformation.

(9) The specific sluggishness in reforms that is compatible with the transition is a practical problem in which transformation is hindered

Although the higher education authorities have a loud voice and move to transform the development of local colleges and universities, the main body for real reform is colleges and universities. If colleges and universities themselves are not enthusiastic about the reforms, the "logistical support" for reforms cannot keep up. Ultimately, the transformation and development of colleges and universities can only become the wishful thinking of the government. Local 
undergraduate colleges or the work procedures that have impeded large-scale reforms are too complex to deal with, or for reasons of unpredictable investment and return rates for the implementation of applied universities, they are in a wait-and-see attitude in the operational aspects of specific reforms.

\section{The Transformation Path}

The transformation and development of newly-built local colleges and universities is not a matter of a certain university, but involves a major system and a major project in all aspects of the government, industry, and society. The transformation of newly-established local undergraduate colleges must be implemented in the practice of running schools. We believe that the main line for the transformation and development of new local colleges and universities should be explored along the following path.

(1) Facing "local" and "application", scientifically determining and accurately grasping the orientation of running a school

Transformation and development are important prerequisites for the orientation of running a school. Positioning for running a school is the direction of choice for transformation and development. The principle of sustainable development shall determine the school's development goals, types of education, service orientation, school-running level, school-running forms, school-running characteristics, personnel training goals, to reflect its school-running philosophy, development direction, goal, and construction priorities. If the orientation of running schools deviates from the direction of serving localities and cultivating applied talents, there is no need to match the needs of local economic and social development.

(2) Changing traditional concepts and creating evaluation indicators suitable for applied technology-oriented universities

To realize the successful transformation of newly-established local universities to applied-tech universities, the first thing we face is to break the division of the traditional concepts such as 369 and 1989, so that the two universities are equivalent in terms of their orientation. Therefore, our country must change the past unfair measures that have consistently adopted academic evaluation criteria to evaluate all colleges and universities, and train highly-skilled talents at the lowest level of the rankings, based on the needs of the local economy and the characteristics of the university itself.

(3) Innovate the school management system to promote organizational management transformation

The transformation of colleges and universities is a systematic innovation project. It is necessary to consciously carry out organizational innovation and management innovation in the process of transformation. Faced with the new situation of economic and social development and the development of higher education, the newly-built undergraduate colleges have not done enough to promote the reform and innovation of the internal school management system and have been unable to adapt to the new requirements of the current development in transition. Therefore, in order to meet the needs of transformation and development, newly-built undergraduate colleges and universities can use the reform of the management system within the school as a starting point and accelerate the transformation of the organization management.

(4) Enhance the quality of teachers and management personnel and promote the transformation of team building

No matter what kind of level or style of transformation is needed, a prerequisite is needed. This is whether the school's teaching staff and management team can successfully transform. University teachers and managers are two important forces for the cultivation of applied talents in newly-built universities, and the construction of teachers and management teams is the key to success. (2)On the one hand, we must create a high-quality teaching staff suitable for the training of applied talents. On the other hand, we must build a management team with strong leadership skills. It is an important issue. Therefore, in order to meet the new requirements for transformation and development, school management cadres need to further emancipate the mind, seek truth from facts, advance with the times, and enhance scientific decision-making capabilities; further scrutinize the 
overall situation, coordinate all parties, make overall plans, improve school management standards, and further seek truth and be pragmatic To overcome difficulties, diligent and clean government, and improve the style of leading cadres.

(5) Strengthening the work of science and technology services to promote the transformation of school functions

With the establishment of the functions of modern universities and the transformation of the new-founded universities, the functions of scientific research, social services, and cultural leadership have been fully utilized in addition to the teaching-centered talent cultivation function. This is an undergraduate institution. On the one hand, the newly-built undergraduate colleges provide intellectual support for social services through talent cultivation, and on the other hand, they serve the development of local economy and society through scientific research and scientific and technological activities. The output of scientific research has not formed a mechanism for combining the production, study and research of well-run applications.

(6) To create local characteristics and speed up transformation

The "National Long-Term Education Reform and Development Plan Outline (2010-2020)" (2) proposes that the structure of higher education should be more reasonable and distinctive, and the characteristics of higher education should be promoted. All colleges and universities are required to overcome the tendency of homogeneity, form their own ideas and styles of running schools, and establish characteristics at different levels and in different fields. The establishment of new local universities is based on the needs of local economic and social development. Facing the fierce competition in the talent market and the challenges of reform and innovation in colleges and universities, how to break through the disadvantages and bottlenecks of running a school with a short history and relatively weak foundation, to create a way for their own school. The dialectical unity of the inherent laws and external laws of higher education shows that the fundamental reason for the survival and development of newly-built local universities that rely on the region is to insist on serving the local economic and social development, and only take the initiative to adapt to society and serve localities.In a nutshell, all the characteristic construction of the newly-built local undergraduate colleges in the transitional development should not leave "local", that is, they cannot leave the needs of the localities. Because all the features of running a school must be concentrated and internalized into a synergistic effect with local economic and social development, and realizing the goal of common development between the school and the local government is of real value.

(7) Adjusting the distribution of disciplines and disciplines and promoting the transformation of disciplines

The construction of disciplines is the key to the transformation and development of schools. Schools should focus on discipline construction and follow the idea of "professional group docking industrial chain serving the local economy and the advantages of the docking location of featured disciplines to promote the development of local industries". To meet the needs of local economic and social development, schools should adjust the discipline structure and set applied disciplines. Disciplinary structure and other undergraduate colleges in the region are dislocated and matched with the local industrial structure. Through the development of applied disciplines to promote the application of professional construction and the construction of applied teachers, and gradually build to adapt to local governments .The application engineering professional groups that require the training of applied talents in enterprises, industries, and enterprises have initially established a new mechanism for the cultivation of distinctive applied talents and a distribution of disciplines and disciplines in line with the transformation of disciplines.

(8) Optimize the training plan and promote the orientation and transformation of personnel training

The orientation of personnel training refers to the requirements for personnel training objectives and specifications in colleges and universities. The thinking of the transformation and development of newly-built undergraduate colleges and universities and the characteristics of their orientation should be implemented in the whole process of the cultivation of applied talents and implemented in all aspects of the cultivation of applied talents. The talent training program is an overall design 
blueprint and implementation plan for realizing personnel training objectives and basic specifications. It is also an important prerequisite for the transformation of the newly-built undergraduate colleges and universities to promote the cultivation of talented personnel and institutional guarantee for the cultivation of qualified applied talents. It should show the flexibility and adaptability of the curriculum, the basic and diversity of the curriculum system, and the application and openness of the practical teaching content system.

(9) Selection of sound application materials

Applied textbooks are knowledge carriers that embody teaching content and teaching requirements according to certain educational laws and regulations according to application-oriented education training objectives and local needs. They are basic tools for cultivating applied talents and teaching activities. It is necessary to improve the evaluation index system of applied textbooks. Reforming the current textbook selection model for local universities and colleges, "breaking the traditional practice of using one textbook in one course and advocating the diversification and quality of college curriculum teaching books."

(10) The organic integration of production and education and the establishment of a mechanism for linking the professional chain with the industry chain

In the transformation and development of newly-built local undergraduate colleges, we must adopt government-led, actively integrate into the development of local industrial industries, make full use of the combination of the industrial industry's self-interests and universities, establish a carrier and platform for implementation of transformation, and promote the integration of education and production methods.

(11) Deepening cooperation between schools and enterprises and building a complementary and win-win "two-subject" school-running model

Newly-established local undergraduate colleges and universities shall implement the transformation of their schools to meet the needs of local economic and social development. They must abandon the traditional academic concept of talents and quality and replicate the practice of the "key university" personnel training model, deepen cooperation between schools and enterprises, and innovate the model of school running. All elements constitute "integration of work and study, teaching and integration" to cultivate applied talents and jointly develop practical scientific research and technology. The development of the "dual-subject" school-running model. To solve the school's constant loss of local advantages or industry background, the effectiveness of school-enterprise cooperation is not high, school education and social needs out of touch.

(12) Build a cooperation platform to form a carrier for the benign and interactive development of schools and enterprises on campuses

The transformation and development of newly-established local undergraduate colleges need to establish a collaboration innovation platform for cooperation between industry, universities and research institutes with local governments and enterprises, implement synergies and complementarities between functions and resource advantages, and implement organic integration and integration of technological innovation, scientific research achievements transformation, and personnel training, and then realize Interactive and win-win development.

(13) Strengthen assessment and assessment, promote transformation and development, and provide services for local implementation

The starting point and end result of the transformation and development of newly-built local colleges and universities is to better serve regional economic and social development and achieve their own development. Whether or not the transformation and development are successful, after the school determines the orientation of running a school and the implementation plan for transformation and development, it depends on whether or not the various reforms in transition are implemented, and the degree of intervention and contribution to regional economic and social development.(3) To this end, we must establish an assessment system for the transformation and development of newly-established local universities.

(14) Local colleges and universities carry out supporting reforms and do a good job in logistical support for transformation 
Under the protection of the government's policy, if the local undergraduate colleges and universities cannot carry out targeted and coordinated changes, the corresponding policy documents will only be empty-handed and lack timeliness. Therefore, local undergraduate colleges should carry out all-round reforms from hardware facilities to the software environment in accordance with the guidance of government policy documents, combined with the requirements of local economic development and their own school-running characteristics to ensure smooth transition. The first thing that should be changed is the previous academic space environment layout, the establishment of classrooms, practical venues, training rooms and laboratories for the training of skilled personnel. In terms of the employment and training of local college teachers, local colleges and universities must change the previous teacher qualifications bureau that emphasizes theoretical practice, and pay attention to the teacher's skills training, so that the transformed college teachers can integrate knowledge and skills into a "dual division”.

(15) Increase the innovation of school running mechanism

Institutional innovation in running schools is a systematic project for the construction of applied universities. Within local universities, we must focus on steadily implementing reforms, formulating various institutional mechanisms suitable for transformation and implementing them, and accelerating the transformation of newly-built local colleges and universities.

\section{Conclusion}

Accelerate the transformation and development of newly-built local colleges and universities, so that the newly-built local colleges and universities can enter the training of applied talents as soon as possible, and cultivate more applied-type undergraduate talents for the society, so as to promote the local economy to develop better.

\section{Acknowledgement}

This paper is one of the Phased Achievements of the "Thirteenth Five Year Plan" Project (16ZD043) in Jiangxi Education Science.

\section{References}

[1] Peng Xinping. Study on the Teaching Reform of Course Network Business Start up in Institutions of Higher Learning. 2015 International Symposium on Engineering Technology, Education and Management [J], 2015.

[2] Peng Xinping, Zhang Xiumei, Chen Yongxiu. Research on the Cultivation of College Students' Entrepreneurship Talents[J]. China Adult Education, 2013(24). 